\title{
Research on the Integration Mechanism of Communication Technology Specialty
}

\author{
Xueqin Jiang \\ Sichuan Vocational College of Information Technology, Sichuan Guangyuan, 628017, China
}

\begin{abstract}
In China's rapid economic and social development, economic restructuring and industrial upgrading, the phenomenon of homogenization appears in university development, and students are facing the problem of difficulty in employment and so on, so it urgently needs for high-level application-type talents. Some local Colleges and universities transform to application-type talents, and the integration of production and education beyond doubt plays an important role in it. But for the communication technology specialty, which has strong practice, the integration of production and education can improve the students' technology application level and improve the employment rate. This paper through the analysis of the theory of the integration of production and education, as well as the analysis of the causes of the integration mechanism of the production and education, and puts forward the integration mode of the communication technology specialty production and education integration mechanism and the implementation points of the integration.
\end{abstract}

Keywords: Application-type; communication technology; production and education integration.

\section{Introduction}

With the increasing number of higher education, the employment problem of College graduates has become increasingly prominent, on the one hand graduates are difficult to find a job, on the other hand, employers cannot recruit the appropriate talents, and this contradiction is more concentrated reflected in the newly-built undergraduate Colleges, 50\% of the graduates each year in about 3400000 graduates coming from the newly-built undergraduate Colleges. One of the core reasons is that the homogenization of among the newly-built undergraduate Colleges and universities, and between the newly-built undergraduate Colleges and traditional universities, and the students cultivated are separated with the application-type that the society needs. In consequence, in the face of the new normal state and new needs of China's economic development, in February, 2014, the State Council executive meeting proposed to lead a part of local Colleges and universities to transform to application-type College. In May, 2014, under the leadership of the Ministry of Education, the National University of Technology Alliance and Chinese International Education Exchange Association held the integration of production and education development strategy international forum in Zhumadian city of Henan Province, which is firstly facing to undergraduate Colleges. In the forum, there are a total of 178 undergraduate Colleges and universities across the country participating in, around the theme of the development of the integration of production and education, all Colleges and universities discuss some problems related to the transformation and development of local Colleges and universities, and issue a "Zhumadian consensus", and then the transformation and development of local Colleges becomes the hot topic of the era.

However, the transformation of ordinary undergraduate Colleges and universities to applied undergraduate Colleges and universities is not a simple process. It includes many factors, such as the transformation of concept, the transformation of teachers' structure, the reform of talent cultivation mode, the reconstruction of curriculum system, the reform and innovation of teaching methods and so on, and the integration of production and education and the cooperation of school and enterprise play a vital role in the process. Only by deepening the integration of production and education can Colleges and universities achieve effective transformation and cultivate the high quality of applied talents that the community needs. In recent years, some local Colleges and universities put forward the road of applied development, make many exploration and practice in the development of the integration of production and education, and achieve successful experience needed to be summed up and studied. 


\section{Analysis on the Causes of the Establishment of the Integration Mechanism of Production and Education}

\subsection{Slow Integration of Production and Education Legislation}

The integration of production and education development is not guaranteed by the policy support, shown as the following four aspects. The first is that the responsibilities and rights are not obvious of the non-educational institutions that take enterprises, universities, industry association as representatives participating in the cooperation of schools and enterprises and the integration of production and education, lacking necessary monitoring and restrictions of laws of enterprises, Colleges, and industry associations, and inadequately protecting the interests of various parties. The second is that the government has not issued a reward and punishment mechanism, do not set specific standards for supervision and inspection of the integration of production and education, and there is no reasonable design of a variety of rewards and punishments measurements.

Table 1 [1] shows the main problems of the integration of production and education for all types of Colleges and universities. From the data in Table 1, it is known that various colleges and universities are facing a lot of problems in the integration of production and education, such as the lack of policy support, lack of funds investment, not mature external environment and so on. However, the most prominent problem is the lack of legal support. For ordinary undergraduate Colleges, the lack of legal support accounts for $58.32 \%$, which is the most urgent problem in all the problems.

Table 1 Main problems existing in the integration of production and education carried out by various Colleges and universities

\begin{tabular}{ccccc}
\hline Main problems & $\begin{array}{c}\text { All the } \\
\text { Colleges }(\%)\end{array}$ & $\begin{array}{c}\text { Research } \\
\text { Colleges(\%) }\end{array}$ & $\begin{array}{c}\text { Teaching } \\
\text { Colleges(\%) }\end{array}$ & $\begin{array}{c}\text { Vocational and } \\
\text { technical } \\
\text { College(\%) }\end{array}$ \\
\hline $\begin{array}{c}\text { Lack of laws support } \\
\text { Lack of funds investment }\end{array}$ & 60.57 & 47.06 & 58.32 & 76.32 \\
Not mature external environment & 52.07 & 50.98 & 41.68 & 61.18 \\
Not establish organizational & 48.51 & 45.1 & 50.08 & 63.16 \\
$\begin{array}{c}\text { guarantee } \\
\text { Lack of coordinating institutions }\end{array}$ & 20.34 & 11.76 & 46.22 & 53.95 \\
Lack of intermediary services & 20.34 & 29.41 & 21.01 & 21.71 \\
sector & 2.64 & 0 & 19.66 & 18.42 \\
Others & & 2.86 & 3.29 \\
\hline
\end{tabular}

\subsection{Lack of Fiscal Policy in the Integration of Production and Education}

At present, China has not established special funds on the integration of production and education. Compared with the ordinary undergraduate Colleges and universities, the national investment in school education is far from enough, the funding for running a school is very insufficient, and the problem of debt of some Colleges and universities are even solved in a long time. From the Colleges and universities, if they can, through the research projects, invest project funding for the majority of teachers, it will be a good way to solve the shortage of scientific research funds in Colleges and universities.

R\&D and the ratio of R\&D in GDP are the essential indexes to measure country supporting the integration of production and education and strengthening the competitiveness of science and technology. China's R\&D investment funds is increasing year by year, but compared with the rapid growth of GDP, it is not enough, which has become an important obstacle to China's development in the integration of production and education. Analyzing the data in Table 2, it is obtained that over the past few years, China's R\&D spending is gradually increasing, and the ratio of R\&D in GDP is also increasing. In general, the total investment is large, but the investment intensity is not strong, planning to reach $2 \%$ in 2010. But from the data in Table 2 [2], it is seen that the index only reaches $1.76 \%$ in 2010, while the ratio of R\&D in developed countries in GDP reaches $2.5 \%$, which is a very obvious gap. That the ratio of R\&D in GDP is low indicates that the funding investment of the state in the development of the integration of production and education is in severe shortage, so both universities 
and enterprises do not have the funds guarantee, which results in that it is difficult to carry out the integration of production and education.

Table 2 R\&D expenditure and the percentage of R\&D expenditure in GDP in 2005-2014 in China

\begin{tabular}{ccc}
\hline Year & Internal expenditure of R\&D funding / billion & Percentage of R\&D in GDP \\
\hline 2005 & 2449.97 & $1.34 \%$ \\
2006 & 3003.1 & $1.42 \%$ \\
2007 & 3710.24 & $1.44 \%$ \\
2008 & 4616.02 & $1.54 \%$ \\
2009 & 5802.11 & $1.70 \%$ \\
2010 & 7062.58 & $1.76 \%$ \\
2011 & 8687.01 & $1.84 \%$ \\
2012 & 10240 & $1.98 \%$ \\
2013 & 11847 & $2.08 \%$ \\
2014 & 13400 & $2.10 \%$ \\
\hline
\end{tabular}

Note: data source: China Statistical Yearbook of 2005-2014

\subsection{Lack of Organizational Support in the Integration of Production and Education}

At present, our government has not established special coordination agency to be responsible for the design, examination, assessment, supervision and evaluation of the integration of production and education, which results in that the project itself lacks inherent power, and business unit in charge of industry department, finance department, labor department and other departments, because of benefits allocation problem, have no great support. The integration of production and education can only rely on the old relationship and existing reputation to support, so without organization coordinating role, it is difficult to form long-term effective organization guarantee system [3]. In order to enhance coordination between each other and ensure the effectiveness of the organization operation of the integration of production and education, it is necessary to establish multi-level coordination mechanism from the central to local levels of government departments, and between universities and enterprises industries, clearly give the responsibility and authority of coordination institutions of the integration of production and education, and increase organizational guarantee ability of the integration of production and education.

\subsection{Lack of Evaluation System of the Integration of Production and Education}

The integration of production and education similar to school teaching work, if we want to maintain sustained and healthy development, we must build a scientific and rational evaluation system. Because the attention that our country paid to the evaluation system of the integration of production education is not enough, up to now, the evaluation system of the integration of production education is not very perfect. The connotation and extension of the integration of production and education need the rationalization of cultivating the quality and management level of talents. At the same time, it also needs the benefit of the enterprises production, the cost of the enterprise cooperation, the quantity of the professional engineer and so on. Only by means of an effective and operable evaluation system can we test the effectiveness and correctness of the integration of production and education. The evaluation system of the integration of production and education has not established expert assessment agencies whose responsibility is, in the projects of the integration of production and education, to pay attention to the development and evaluation between the parties, cautiously investigate them, and avoid fraud and deceit of the parties.

\section{Establishment of the Integration Mechanism of Communication Technology Specialty}

\subsection{Integration Mode of Production and Education of Communication Technology Specialty}

Firstly, the curriculum system setting is combined with the job requirements, focusing on the practical requirements of the post. Set up the curriculum system according to the requirement of enterprise position, strengthen the pertinence and application of communication technology specialty courses and training courses. Improve the intensity of the integration of professional courses, further 
standardize the curriculum, and promote the personnel training between Colleges and enterprises. The second is the combination of basic theory teaching and basic skills training, focusing on the training of the basic skills of students. Basic theory teaching includes basic knowledge and professional knowledge, and basic skills training refers to, on the basis of knowledge, activities formed through the practice and mental activities. Moreover, it is the combination of communication technology professional theory teaching and practice teaching, focusing on strengthening the practical teaching link. Professional theory teaching should be carried out according to the needs of jobs of students in the future, and practical teaching should be based on the theory of teaching, to achieve the combination of learning and using. The practical teaching is conducive for the students to obtain direct knowledge and experience knowledge so that they can use the theoretical knowledge to solve specific problems, which also cultivates students' awareness and ability to operate independently.

\subsection{Implementation Key Points of the Integration of Production and Education of Communication Technology Specialty}

\subsubsection{Talent Training Program around the Professional Core Competence}

For applied talents, the professional core competence is of great importance. For students, professional core competence can help students to better adapt to the environment of occupation position, acquire new knowledge and skills in the new environment, and also expand the students' employment space after graduation and self-promotion space. In terms of enterprise, it is necessary for enterprises to improve their professional core competence for enterprise to enhance competitiveness. Integrate the professional core competence into the course system of the communication technology specialty and the daily teaching [4]. Take measures to carry out the reform and innovation of talents training program of the communication technology specialty. Communication technology specialty, before amending the training plan, needs to dispatch department leaders, school leaders, professional teachers to research on the needs and requirements of enterprise industries for applied talents, but also invite enterprises experts to discuss, study, and amend the talents training plan, and actively accept the advice of experts in enterprises (industry) in the process, so as to make the professional core competence training throughout the whole process of talents training.

\subsubsection{Innovation and Entrepreneurship Education Running through the Process of Talents Training}

Innovation and entrepreneurship education is an effective way to implement the integration of production and education. The implementation of innovation and entrepreneurship education is conductive to improve the overall quality of students, enhance students' innovation ability and the entrepreneurial ability on the basis of innovation, help students to change their concept of employment, to foster entrepreneurial awareness, to establish entrepreneurial confidence, to grasp entrepreneurial skills, and to improve the ability of entrepreneurial management, so as to promote effective development of the integration of production and education in the communication technology professional. Strengthen the connotation construction of the cooperation of school and enterprise, integrate enterprise resources, build a diversified mode of school and enterprise cooperation, and provide a solid support for the talents training mode of innovation work - study combination. Closely connect the theory and the practical application, and improve the teaching design of the experimental teaching and the technical theory correspond to the practice in teaching link; construct the course system of work - study combination. According to the specialty, choose cooperative enterprises, cultivate talents by cooperating with enterprises, and improve the training program of work - study combination.

\subsubsection{Role of Enterprise in the Cultivation of Professional Core Competence}

Enterprise is an important driving force and the implementation body for the integration of production and education and the cooperation of school and enterprise. Enterprise is the maker and appraiser of the standards for the cultivation of professional core competence, which is also the participant and the executor of the training of professional core competence. Only by ensuring the important role of enterprises in cultivating the professional core competence, can we truly achieve the 
five requirements for the integration of production and education, namely docking of professional setting and industry demand, docking of course content and occupation standard, docking of teaching process and production process, docking of graduation certificate and occupation qualification certificate, and docking of occupation education and lifelong learning [5]. For students majoring in communication technology to realize the combination of production and teaching, they are supposed to as much as possible participate in practice and training, transform the theoretical knowledge learned at school into practical experience, and internalize as professional core competence, which is of great importance. The enterprise, as one part of the integration of production and education and the cooperation of school and enterprise, plays an essential role in cooperating with school to construct experiment, practice, and training platform.

\section{Conclusion}

Currently, the requirements of the development of China's higher education is that the higher education must combine with national economy industrial upgrading and regional economic transformation and industry construction needs, cultivate high-quality applied talents who are helpful for the society and enterprises. Many applied undergraduate universities have begun the practice of the integration of production and education to meet the needs of a large number of applied talents of the enterprise and the society. This paper, mainly through the integration mechanism of production and education with strong practice to discuss, in the combination of production and education, not only the school, but also the enterprise, are the important subject and the enterprise is the really appraiser.

\section{Acknowledgements}

The national ministry of industry and information technology professional education teaching steering committee (TXZZW2016051)

\section{References}

[1] Afanasev A, Letyaev V, Minsabirova V, et al. Integration processes in education: Classification of integration types [J]. 2015.

[2] Shaidullina A R, Masalimova A R, Vlasova V K, et al. Education, science and manufacture integration models features in continuous professional education system [J]. Life Science Journal, 2014, 11(8): 478-485.

[3] Shaidullina A R, Pavlova N A, Minsabirova V N, et al. Integration processes in education: Classification of integration types [J]. Review of European Studies, 2015, 7(4): 27.

[4] Shaidullina A R, Krylov D A, Sadovaya V V, et al. Model of vocational school, high school and manufacture integration in the regional system of professional education $[\mathrm{J}]$. Review of European Studies, 2015, 7(1): 63.

[5] Decouttere C, Vandaele N, Lemmens S, et al. Performance evaluation of a supply chain design by the integration of production capacity into the guaranteed service approach [J]. 2016. 